Revue belge de géographie

4 | 2016

Sustainability of rural systems: balancing heritage and innovation

\title{
Negotiating the State-making in Vietnam borderland - Case study of an ethnic minority group in Central Vietnam
}

Négocier la formation de l'Etat à la frontière vietnamienne: étude de cas sur un groupe ethnique minoritaire au centre du pays

Trinh Nguyen Minh Anh, Doo-Chul Kim and Fumikazu Ubukata

\section{Q OpenEdition}

\section{Journals}

Electronic version

URL: http://journals.openedition.org/belgeo/19409

DOI: 10.4000/belgeo.19409

ISSN: 2294-9135

Publisher:

National Committee of Geography of Belgium, Société Royale Belge de Géographie

Electronic reference

Trinh Nguyen Minh Anh, Doo-Chul Kim and Fumikazu Ubukata, « Negotiating the State-making in Vietnam borderland - Case study of an ethnic minority group in Central Vietnam », Belgeo [Online], 4 | 2016, Online since 31 December 2016, connection on 30 April 2019. URL : http:// journals.openedition.org/belgeo/19409; DOI : 10.4000/belgeo.19409

This text was automatically generated on 30 April 2019.

Belgeo est mis à disposition selon les termes de la licence Creative Commons Attribution 4.0 International. 


\title{
Negotiating the State-making in Vietnam borderland - Case study of an ethnic minority group in Central Vietnam
}

\author{
Négocier la formation de l'Etat à la frontière vietnamienne: étude de cas sur un \\ groupe ethnique minoritaire au centre du pays
}

Trinh Nguyen Minh Anh, Doo-Chul Kim and Fumikazu Ubukata

\section{Introduction}

In post-socialist Vietnam, the blueprint of most official development policies in mountainous areas is based on the understanding of social and economic structures of the Kinh people, the dominant ethnicity in the nation's population and politics. Mountainous areas, which account for nearly three quarters of the country surface, is home to different ethnic minorities whose livelihood and social organisation are different from those of Kinh people. As a result, ethnic minorities do not usually benefit directly from official development policies that are supposed to create a social and economic homogeneity for convenient governance from official point of view. This State-making process is sometimes considered to be an assimilation of ethnic minorities into the mainstream majority (McElwee, 2004). The paper targets one of those ethnic minorities, the Bru-Van Kieu in Central Vietnam, who have experienced drastic changes in their socio-economic conditions during the last 40 years. Their traditional living environment has transformed from a landscape dominated by seemingly impassable forest where ethnic minority people lived in scattering villages and practiced shifting cultivation to a multi-ethnic congregation settlement engaging in cash cropping and trading. More significantly, the sense of remoteness that once characterised this upland area due to the distance from lowland population centres and subsequently, the minimal territorial and demographic control from central government, has disappeared. Nowadays, modern 
towns are an integral part of the official governing system, well-connected to central political centres by a network of communication systems through local representatives of State authority. The physical transformation in living environments of the Bru-Van Kieu people is not an exception within contemporary Vietnamese society, where the nationState project is characterised by efforts of a postcolonial socialist State to increase its penetration into, and control over, the population and territory in its previously remote frontiers. This process, however, has paid little regard to the pre-existing socio-economic conditions of the indigenous people and has mainly imposed external institutions on them (Michaud and Forsyth, 2010).

This paper aims to describe changes in the socio-political condition of the Bru-Van Kieu peoples living in the border areas between Vietnam and Laos, in the context of increasing State territorialisation. The authors elaborate the mechanisms by which State territorialisation via official development policies have re-shaped the livelihood and traditional governance systems of ethnic minorities in the border areas, including Katup Village. This is followed by a discussion on the response of the Bru-Van Kieu people in Katup Village to the socio-political changes brought about by official development policies. It is argued that State territorialisation, exercised by official development policies, has the tendency to marginalise, socially and politically, local ethnic minority people by excluding them from indigenous social and economic geography and the use of natural resource. At the receiving end of these official policies, the local ethnic minority people do not passively tolerate but are able to initiate the use of both traditional cultural resources and newly arising institutional and market tools to mitigate the impact from the process of official institutionalisation of resources.

\section{Everyday resistance and State-territorialisation}

\section{Moral economy and everyday forms of peasant resistance}

3 James Scott (1976) examined political resistance to State development and market mechanisms using the concept of peasant "moral economy". This concept centres on the principle that peasant communities share a set of normative attitudes concerning the social relations and social behaviors that sustain a local economy. As a result they have a tendency to oppose State authorities, or market forces that are breaching local rules respecting existing social arrangements shaping their subsistence needs. Specifically on Vietnam, Scott (1985) argues that the market threatens the survival of peasant's subsistence economy and traditional social relations that define the operation of this economy. He argues that the peasants, whose priority is to reduce the risk of losing their savings, tend to refrain from engaging in the market. In other words, they would prefer to protect subsistence needs and moral relationships rather than seek to maximise profits. Kerkvliet (2005) further illustrates how the powerless farmers in Vietnam in agricultural cooperatives during the 1970s, unsatisfactory with productivity and benefitsharing mechanisms, struggled in what he terms "everyday resistance". By "everyday resistance", he demonstrates individual covert acts and behaviors such as foot-dragging, non-compliance, petty theft to upset agricultural productivity in order to force more powerful State and market actors into re-negotiation. 


\section{State-territorialisation as a State-making strategy}

4 Internal territorialisation became a key strategy employed by the Vietnamese State to strengthen its control over rural population and natural resources. It aims to control rural people and resources, and categorise territory into zones of inclusion or exclusion of accession right for different social groups (Vandergeest and Peluso, 1995). In other words, Internal-territorialisation defines the relation between the State and society regarding the use of resource and space. In addition to internal territorialisation, Stateterritorialisation includes sovereign territorialisation. Arguably the main difference between internal territorialisation and external territorialisation is the issue of how to control the people. While by internal territorialisation, (e.g. the creation of local administration and resource exclusion) the State aims to control people via different methods of land-based administration, sovereign territorialisation is more about controlling territory by means of border demarcation. In this instance, Stateterritorialisation can be considered to be a strategy of State-building. As a concept, Statemaking is defined as principally about strengthening the relationship between the State and society, and developing effective ways to mediate this relationship (DIFD, 2009). A State-making perspective emphasises that functioning institutions depend not only on their technical design, but on the social context within which they operate. A study from by OECD (2008) highlights that "formal institutions need to be rooted in society otherwise they risk becoming mere shells or being captured by private or patrimonial interests".

\section{Traditional society of the Bru-Van Kieu}

This section describes Bru-Van Kieu society in their traditional form and in isolation from the general population. It is difficult to estimate at exactly what time the Bru-Van Kieu people started to converge with the population of the dominant group, the Kinh, and the influence of the ruling political entity; however, it would be safe to surmise that, before the French colonialism, most of the Bru-Van Kieu villages were still in a primordial form and isolated from the "civilised" world of the Kinh people. The Bru-Van Kieu organise a patriarchal society where the eldest male is usually the head of the family. Inheritance is exclusively the right of the male members. Married couples live with the husband's family, and their children bear the paternal name. A man is permitted to marry as many wives as he can afford.

6 The Bru-Van Kieu generally did not have a socio-political structure beyond the village level; that is to say, the village is most fundamental social organisation. Each village (vel) consists of one or more lineages $(\mathrm{mu})$. Within each lineage, authority rests with the eldest male member (Nguyen, 2001). A council of elders, consisting of the heads of each lineage, often gathered to discuss matters that concern multiple families. The council of elders makes decisions concerning war, relocating the village, great hunting parties, settling conflicts between families, the appropriate sanctions for serious violations of tribal custom, and tradition. When the village deals with outsiders, such as inter-village conflicts, the patriarch, who is usually the wealthiest or most powerful member of the council of elders, usually represents the village in settling the issue.

7 In the many cases in which one lineage formed the village, the patriarch was the head of that lineage. In this homogeneous political landscape, the patriarch was a chief, not a 
ruler. He and his family had to work for their food like other villagers. The Bru-Van Kieu practiced a subsistence economy, primarily based on dry rice cultivated by the slash-andburn technique. In short, this technique involves cutting down and burning all vegetation within a forested area. The resulting ashes serve as fertiliser, which helps the field sustain a crop for three to four years. Crops grown by this method depended solely on rainfall for irrigation. When the field is no longer fertile enough to support crops, the farmer finds another tract of forestland and starts a new cycle of slash-and-burn, allowing the old fields to rehabilitate back to forest. The Bru-Van Kieu diet is supplemented by the cultivation of corn and beans, and meat from hunting and fishing. Several authors have claimed that this tribal group has traditionally bartered their goods, either among themselves or with the Kinh merchants traveling to their village or to a nearby market town (Nguyen, 1984; Schrock et al., 1966). Land was the common property of the village and allotted to families for the cultivation of crops. The power of making land allocation decisions rest on the authority of the council of elders and the village patriarch. Since the Bru-Van Kieu follow animism, several successive losses of crop or multiple deaths would lead the patriarch to believe that the village is haunted by an evil spirit, which could result in a decision to move the entire village to a new location.

\section{Interaction betweenthe Bru-Van Kieu and dominant ethnic and political groups}

\section{Pre-colonial period (1620-1885)}

Written accounts of the contemporary history of Central Vietnam socio-politics just before the French arrived can be found exclusively in the official record of Phủ biên tạp luc 1. The author, Lê Quý Đôn (1776) described that lords of the Nguyen ${ }^{2}$ recognised the existence of several tribal groups on the western upland. The official ruling court addressed various ethnic groups in western upland region (Fig. 1) without any distinction by the term "mọi" meaning "barbaric" and "savage" to discriminate them from more populous lowland Kinh people. On a trip to western upland of Thuan $\mathrm{Hoa}^{3}$ he noted the presence of different "uncivilised" ethnic groups. There is a high chance that modern Bru-Van Kieu people are descendants of the ethnic community living in Vien Kieu area described by Lê Quý Đôn in 18th century. More importantly, it was noted that these “ barbaric savages" were not registered individually in official record system for taxation purposes. The most significant interaction between residents of Vien Kieu area and Kinh lowlanders was the exchange of goods where Kinh lowlanders traded salt, fish sauce, dried fish, iron wares, copper pots, silver hairpins and bracelets for rice, chicken, oxen, hemp, wax, rattan and cotton cloth woven by uplanders (Li, 1998). 
Figure 1. Part of Central Vietnam.

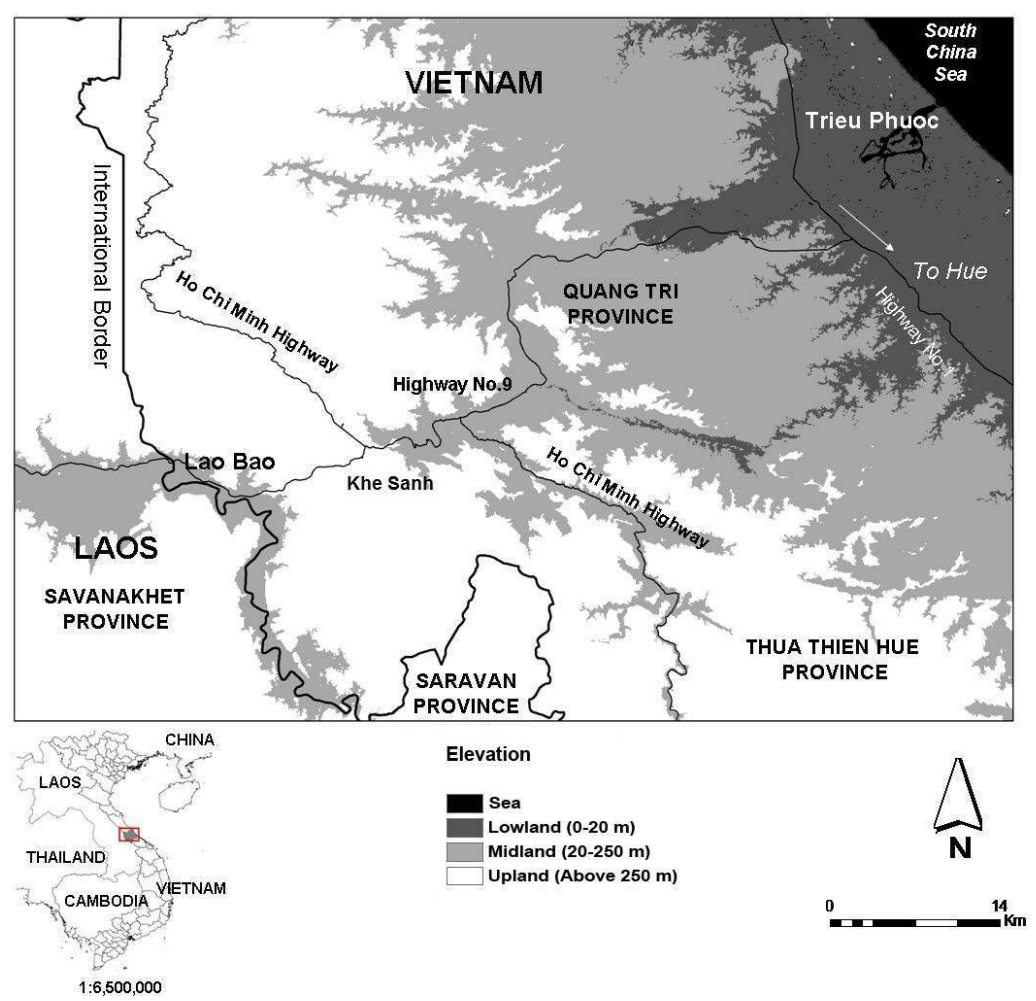

In Phủ Biên it is frequently mentioned that Nguyen lords preferred to avoid unnecessary conflicts with major tribes in pre-colonial Laos. This gave resonance to the thinking that conquering the territory and population of the Thuan Hoa western mountainous area was not a political and military priority of the Nguyen (Li, 1998). In fact before the French colonialisation the western mountainous flank of what is now Quang Tri Province was under contested influence of different Laotian tribes, Siamese Kingdom and the Nguyen (Stuart-Fox, 2008). Li (1998) also pointed that even though Kinh people started to push their population to Thuan Hoa hinterland, intermarriage between Kinh lowlanders and local ethnic minorities was limited reflecting Vietnamese prejudices on the barbaric and savage culture of tribal minority peoples.

In summary, before European colonialism controlling Bru-Van Kieu area was not a pressing concern of the Nguyen, the dominating official political and military power at that time, because the latter found their quest to the south and defense to the north a higher priority. Apart from a small population engaged in trading with lowlanders, most tribal peoples in the mountainous west of Quang Tri Province preferred to keep a social distance from Vietnamese migrants. Being out of easy reach of political centres of the Vietnamese, Laotian and Thai people and keeping Vietnamese migrants as stranger helped ethnic minorities in the western mountain of modern Quang Tri province in general and the Bru-Van Kieu in particular retain their unique culture and autonomy.

\section{French Colonial period (1885-1954)}

The Western mountains of Quang Tri province, then, part of French Annam Protectorate, played an important role in French administration for its connection with Laos, another French colony. Although several French colonialists set up coffee plantation on the basalt 
soil in Khe Sanh valley they did not come into close contact with local Bru-Van Kieu people because they all preferred to bring Kinh lowlanders to work as plantation cullies (Le et al., 1993). In his anthropological survey in Central Vietnam, Hickey (2002) described that by mid-20th century, however, a few Bru-Van Kieu people living in Khe Sanh sold their labour periodically but not steadily in several coffee plantations for cash. They, for the first time in Van-Kieu history, encountered the international commodity chain as Khe Sanh coffee was famous in Indochina in early 1960s (Hickey, 2002). For the majority of Bru-Van Kieu population to the west of Khe Sanh, the influence of lowlanders and the French was limited. The French administration requested Bru-Van Kieu villages to pay a small amount of tax, however, it is unclear via which instrument and to what extent the French could enforce this policy (Schrock et al., 1966). When Vietnamese nationalists found a footing in western forested mountains to mount their resistance against the French, thus, inviting retaliation from the latter and together increasing hostility in the area, most Bru-Van Kieu apart from those residing in Khe Sanh opted to escape into deeper forest and mountains where they felt safe to avoid conflict (Le et al., 1993).

\section{Second Indochina War (1954-1975)}

Different governments of the southern Republic of Vietnam attempted to substitute State law with tribal customary rules to integrate upland communities into official power (Schrock et al., 1966). This effort in the area of the Bru-Van Kieu in western Quang Tri had little chance to be implemented because the area had never been in full control of southern governments for its close proximity to, hence heavy influence from the State of northern Democratic Republic of Vietnam ${ }^{4}$. Communist infiltration and insurgency started as early as 1959 along National Route 9 (Nguyen and Nguyen, 2010). During the Second Indochina War, the forested mountain of Annamite Cordillera ${ }^{5}$ was hardly a safe haven for anyone as the American military relentlessly raided both the eastern and western sides of the range by sky and ground forces to block an increasingly fluid network of crucial trails transporting men, supplies and weapons from the northern socialist to their comrades in the south in the struggle against southern capitalists and their allies (Stuart-Fox, 2008). With little space left untouched by the war, most Bru-Van Kieu in Huong Hoa district had no choice but to reluctantly ally with different political and military entities made of lowlanders. In 1965, the government of the Republic of Vietnam resettled many Bru-Van Kieu people from their remote area to a three-mile strip on each side of National Route 9 in Khe Sanh to pre-emptively prevent their assistance to pro-socialist forces (Schrock et al., 1966). It is estimated that ten thousand Bru-Van Kieu concentrated around Khe Sanh valley when different US military camps started occupying this location in the early 1960s. Among them around 1,000 men were on the payroll of the American military (Clarke and William, 2007). According to McElwee (2008, p. 95) the Bru-Van Kieu in western Quang Tri at this time "were on the horns of a dilemma. If they farmed close to the settlement, there was insufficient land and the Communists harassed them for being pro-government; if they farmed out where land was plentiful the government suspected them of supporting the Viet Cong."

At the same time Bru-Van Kieu people to the west of Khe Sanh valley were under the influence of the North Vietnamese Army (NVA). A memoir of Nguyen Khac Nguyet (2009), a NVA veteran, described vividly the support from Bru-Van Kieu people in late 1960s to his unit during their offense on American military position. In fact, Nguyet's memoir is 
only one of many published and unpublished accounts from war veterans devoting part of their content to illustrate the allegiance of Bru-Van Kieu in the Second Indochina War. What can be concluded is that Bru-Van Kieu people were reluctantly dragged into the conflicts of other dominant ethnic and political groups when their neutral and evasive tactic to avoid direct confrontation was no longer an option. After the war, Bru-Van Kieu people in Khe Sanh came back to their former village. The Bru-Van Kieu who found asylum in Laos also returned to their home village. For both pro-socialist and procapitalist Van Kieu, they all had to start almost from scratch after years of dislocation, in war-contaminated farming land and amidst unchanged attitude from the Kinh majority.

\section{The Bru-Van Kieu in Katup Village}

14 The study site is Katup Village in Lao Bao Town, Huong Hoa District, Quang Tri Province, Vietnam. Katup Village is located on the border between Laos and Vietnam. The research discussed in this paper is resulted from fieldwork conducted in border area between Vietnam and Laos on four occasions, March 2012, October 2012, July 2013 and March 2014 during which the authors spent nearly 8 weeks on the field. For Katup Village, general information regarding local demography, economy and ethnicity was obtained from Lao Bao Town's People Committee before the fieldwork was conducted. After that the authors acquired further information concerning household's number of members, number of labourers, income, livelihood activities, social connections and history of settlement from head of individual households via questionnaire. From a total of 72 households in Katup Village, 69 questionnaires were responded. Among these households, random households were chosen for in-depth interview to gain further detail on cross-border interactions between local Katup villagers with Laotian co-ethnics and also with officials in Vietnam. To gain more insight on this matter, the authors also conducted in-depth interview with 5 Laotian Bru-Van Kieu households at their village in Laos and several officials of Vietnamese Border Patrol. In addition, small group discussions among households with kinship relations were conducted to reveal their cooperation in cross-border activities. At the time of last fieldwork in 2014, the population of Katup Village was at 372. Except for one Pacoh family, all others in the village are Bru-Van Kieu. The language for questionnaire and in-depth interview was Vietnamese. In case a respondent was not proficient in spoken and written Vietnamese, translation and interpretation service from a Bru-Van Kieu translator was needed. Secondary data from official archives and veteran memoir coupled with personal accounts of Bru-Van Kieu was compiled to reconstruct a brief socio-political history of the local area.

\section{History of Katup Village}

15 Elders in Katup Village did not remember how long they have been settled in their current location. What they did remember, and kept recalling, was that their parents and grandparents lived along the Sepon River (Fig. 2) since, in their language, the "time of the French". At the heat of war in the late 1960s and early 1970s, they crossed the river to hide in caves deep in Laos's territory. As early as 1974, the Bru-Van Kieu returned to Katup Village's former location by the river. During the resettlement process, while most households farmed land in Vietnam, a proportion of households started clearing land to farm on Laos's territory. In the late 1970s, following a border demarcation agreement 
between the Vietnamese and Laotian governments, the river was reaffirmed as the political border (see Truong et al., 2007). Katup villagers on both sides of the river were officially asked to choose their nationality and then to resettle to their chosen State's territory. Most of the families chose their nationality based on the location of their farming land. That is, families who had the majority of their farming land in Laos or Vietnam chose to become Laotian or Vietnamese, respectively, as their nationality. Some families moved, in order to re-unite with their immediate families. In reality, Katup villagers did not fully comprehend the significance of the border demarcation and their selection of a nationality at that time. Elders still recall that their life did not change immediately after the border was demarcated, and they quickly forgot that they were then of different nationalities. It was only years later, when border guards increased their presence in that area and started constructing physical representations such as border markers and outposts along the border while constantly giving locals lectures on the topic of political border and national sovereignty, that the Bru-Van Kieu in Katup Village began to realise an institutional barrier was forming between them and their brothers in Laos. Today, in the area of the traditional Katup Village, there are two different villages by the name Katup; Katup Village on the Vietnam side and Katup Noy ${ }^{6}$ on the Laos side.

Figure 2. The relative location of Katup Village.

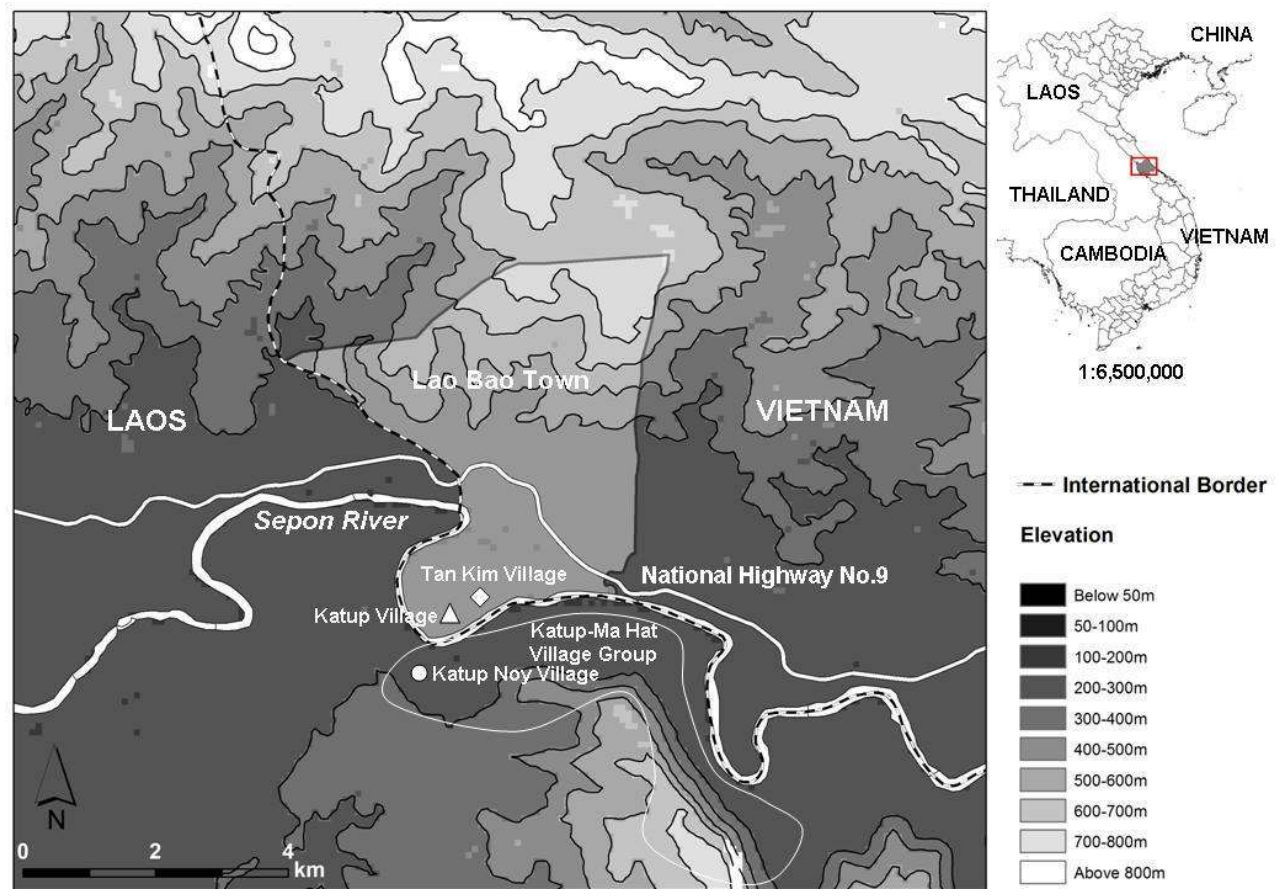

16 Although existing as two separate political entities at the moment, the two villages are still connected by rich patrilineal kinship and marriages. Reciprocal exchange and mutual help are still popular in this small Bru-Van Kieu community. Occasionally, there are gatherings of several households to give collective effort to heavy works, such as forest clearing for agricultural land or constructing a house for a family. Villagers from both sides of the Sepon River will attend a family's marriage and funeral rituals. Gathering of relatives from both sides of the border to drink at the end of the day is a popular social event. Despite the fact that Laotian official authorities address the Bru-Van Kieu community on the opposite side of Sepon River as "Katup - Ma Hat Village Group" (Fig. 
2), the Laotian Bru-Van Kieu, who originate from Katup Village, still address their village using the old name, Katup, in everyday conversations.

\section{Household economy of the Bru-Van Kieu}

17 Swidden farming still plays an important role among Katup villagers. All of the households participating in in in-depth interview indicated that swidden farming occupies a large proportion of their working time, and provides an important food source and income (Table 1). Lao Bao Town is in a basin encompassed by hilly and mountainous terrain to the north and the Sepon River curving around the southwest, leaving a narrow and nearly flat basin in the middle (Fig. 2). Most of the swidden plots used by the Bru-Van Kieu in Katup Village are in the northern, mountainous terrain, adjacent to those of neighbouring communes. Swidden farming among Katup villagers produces two main types of crops: staple-food crops and cash crops. For their staple foods, Bru-van Kieu peoples plant sweet potatoes, corn, beans, and local varieties of corn and dry rice. Cash crops are gradually becoming a major component in the swidden lands of Katup villagers. In the past, chili, peppers, and mangoes were the main crops, but they became unprofitable and were recently replaced by cassava, bananas, and bollywood ${ }^{8}$. Among the interviewed households in Katup Village, swidden plots ranged from 0.5 ha to 2.5 ha (Table 1). The official demarcation of swidden land for Katup villagers ended in 2011, resulting in more than half of the population receiving a Red Book ${ }^{9}$, while the other half already had their land demarcated ${ }^{10}$. Agricultural intensification techniques, such as using machinery or fertiliser, are not popular for staple crops, and as a result, soil fertility depletes within two to three years of harvesting. The lack of machinery and fertilisers is a result of the Bru-Van Kieu's inexperience with intensification technology, a lack of financial investment, and the steep terrain that makes machinery hard to use and the land susceptible to erosion. Among the interviewed households, the majority planted both staple and food crops, while only a small number cultivated a single staple crop, due to the small size of their swidden land (Table 1). The results also indicate that there has been a gradual shift to cash crops, in which cassava ${ }^{11}$ is dominant.

Several families in Katup Village rear chickens and ducks at a small scale, primarily for household consumption. Pigs and cattle are rarely seen in Katup. The sandy tract of soil along the Sepon River is narrow, but suitable for cultivating sweet potatoes and corn in the dry season when the water level is low. The Bru-Van Kieu do not pay special attention to the plants in their garden. Most home gardens are characterised by poorly nurtured fruit plants, such as papayas, oranges, and bananas.

Collecting non-timber forest products (NTFPs) plays an important role in the Katup household economy. When it is not raining, the Bru-Van Kieu people go into the forest to collect bamboo sprouts, wild jackfruit, and young banana flowers ${ }^{12}$. The task usually falls on the shoulders of the household's female members, such as the grandmothers, housewives, or daughters ${ }^{13}$. Another significant source of NTFPs is firewood, usually the by-product of the process of clearing and burning a forest to prepare it for agricultural use. The adult males in a family transport burnt tree trunks from swidden farm to home, split them to firewood, and then sell them to restaurants in Lao Bao Town. Most of the collected products are of commercial value. The female members of a family sell these products, with the exception of firewood, at local markets. On average, each interviewed family earns approximately USD 80 a month from selling NTFPs. A small number of 
households earn an additional USD 100 from timber sales. This task, performed by adult men, involves a small group of close-knit relatives extracting valuable timber from the forest and selling it to local Kinh intermediates or carpenters ${ }^{14}$.

Table 1. Household economy - selected descriptions.

\begin{tabular}{|c|c|c|c|c|c|c|c|}
\hline ID & $\begin{array}{c}\text { No. of } \\
\text { household } \\
\text { members }\end{array}$ & $\begin{array}{c}\text { No. of } \\
\text { labourers }\end{array}$ & $\begin{array}{c}\text { Main } \\
\text { livelihood }\end{array}$ & $\begin{array}{c}\text { Paddy } \\
\text { land } \\
\text { (ha) }\end{array}$ & $\begin{array}{l}\text { Swidden } \\
\text { land (ha) }\end{array}$ & $\begin{array}{c}\text { Swidden } \\
\text { land in Laos } \\
\text { (ha) }\end{array}$ & $\begin{array}{l}\text { NTFPs } \\
\text { collection }\end{array}$ \\
\hline 1 & 7 & 2 & (2) (3) & $x$ & 0.7 & 0.5 & $\checkmark$ \\
\hline 2 & 6 & 2 & (2) (3) & $x$ & 1.2 & 0.5 & $\checkmark$ \\
\hline 3 & 7 & 3 & (1) (2) (3) & 0.2 & 2.1 & 0.5 & $\checkmark$ \\
\hline 4 & 7 & 4 & (2) (3) & $x$ & 1.5 & 2.0 & $\checkmark$ \\
\hline 5 & 11 & 4 & (1) (2) (3) & 1.0 & 1.0 & 0.5 & $\checkmark$ \\
\hline 6 & 3 & 2 & (2) (3) & $x$ & 0.7 & $x$ & $\checkmark$ \\
\hline 7 & 5 & 2 & (1) (2) (3) & 0.1 & 0.9 & 1.0 & $\checkmark$ \\
\hline 8 & 4 & 2 & (2) (3) & $x$ & 1.1 & 1.0 & $\checkmark$ \\
\hline 9 & 3 & 2 & (2) (3) & $x$ & 2.1 & $x$ & $\checkmark$ \\
\hline 10 & 4 & 2 & (2) (3) & $x$ & 1.2 & 1.0 & $\checkmark$ \\
\hline 11 & 5 & 1 & (2) (3) & $x$ & 0.5 & 1.0 & $x$ \\
\hline 12 & 6 & 2 & (2) (3) & $x$ & $x$ & 1.5 & $\checkmark$ \\
\hline 13 & 8 & 4 & (1) (2) (3) & 0.5 & 2.5 & $x$ & $\checkmark$ \\
\hline
\end{tabular}

\section{State territorialisation since 1975}

\section{Official institutionalisation of natural resources and exclusion of local people from their traditional space and resource}

The migration of Kinh people from the lowlands has changed not only the general population of Lao Bao Town but also the local political economy, removing the Bru-Van Kieu people from their traditional role as the exclusive residents and resources users. After national unification in 1975, the State saw replicating the collective agriculture model to the southern and upland regions as imperative, because this model, dominant in the northern Vietnam lowlands since the late 1950s, was regarded as the fundamental pinnacle of socialist ideology pursued by the State (Pingali and Vo, 1992). The official boundary divisions did not consider the traditional culture and production space of the Bru-Van Kieu people. On the other hand, the new boundary had significant implications for the Bru-Van Kieu people, because their residential and agricultural space was, for the first time in history, charted into and administered by the national administrative system. Following this official administrative division, their traditional land became the territory of a different administrative unit, and of its new, "legal" users. Official institutions did not recognise the traditional land system of Bru-Van Kieu people; hence, they did not see the institutionalisation of land in Lao Bao Town in 1975 as an act that took the factor of production away from the Bru-Van Kieu people in order to grant it to Kinh immigrants. Common official discourses described the land in Lao Bao as "unused", "unoccupied", and "barren", and allocating the land to new immigrants was a logical and legal action to prevent the land from being wasted (Nguyen and Nguyen, 2010). Official 
demarcation occurred not only within communes but also between communes, districts, and eventually nations. What the Bru-Van Kieu considered as their rightful and traditional land, cleared by their forefathers and endowed to them by inheritance for generations - considerations that were strictly observed among fellow Bru-Van Kieu people - was, on the contrary, viewed by official authorities as an environment lacking a pre-existing social arrangement. Officials conceptualised the Bru-Van Kieu territory merely as a new unit to be integrated into the large, national physical geography that was subject to official political will and unquestionably outside of the Bru-Van Kieu's political power.

\section{Fragmentation of traditional social geography}

21 International border and its official enforcement threaten to fragmentise a traditional fluid and continuous social and economic landscape of the Bru-Van Kieu. Upon border demarcation, the Bru-Van Kieu were requested by the authorities to sedentarise their settlement, either on Vietnam territory or on Laotian territory. Mobilisation across their traditional social landscape is now restricted by a political border which was only increased with higher presence of State's law enforcement in the form of Border patrol, to control the flow of people, and Customs, to control the flow of material. Since economic reform, foreign trading with Laos through Lao Bao Town has increased significantly. Along with this is an increase in the presence of official law enforcement. In the past, to visit a relative opposite of the river, the Bru-Van Kieu had to pass physical barriers such as river, mountain and the distance between villages. Today, even though those physical barriers might not be as challenging as in the past with the improvement in infrastructure such as road and bridges, they have to overcome political barriers. The river is no longer simply a physical barrier, because to pass it they need permission from authorities Within Bru-Van Kieu area, socio-economic conditions gradually differentiate the Vietnamese side from the Laotian side as a result of different general development state between the two countries. This differentiation threatens the homogeneity of BruVan Kieu society.

\section{The impact of State territorialisation on the Bru-Van Kieu in Katup Village}

\section{Loss of the traditional subsistence agricultural system}

During the period of collective farming, from 1975 through the early 1990s, the Bru-Van Kieu in Katup Village were encouraged to join Tan Kim $2^{15}$, a production unit that already consisted of a portion of the households in Tan Kim Village, newly established by immigrants from Trieu Phong Commune. In order to make space for a residential area for new arrivals and collective farming land, Tan Kim 2 production unit appropriated the flat area along the Sepon River which happened to be part of the landholdings of several BruVan Kieu households. The Bru-Van Kieu faced competition over land not only from the production unit but also from individual Kinh households. Collective farming did not provide enough food for the immigrant population, and as a result individual immigrant households sought extra swidden land on which to plant their own household crops (Nguyen and Nguyen, 2010). Often they cultivated into tracts of land that appeared 
forested and unused, but were in fact already under the traditional ownership of Bru-Van Kieu households. In such interethnic land disputes, indigenous and immigrant claimants often negotiated a solution acceptable to both parties, frequently in the form of material compensation from Kinh household to the Bru-Van Kieu household in exchange for land. Nonetheless, if the plot of land in dispute was outside Lao Bao territory, the Bru-Van Kieu in Katup Village faced the possibility of losing their traditional land, because the Kinh claimant would use the official land division between production units and communes as leverage to argue that the Bru-Van Kieu villagers did not have the right to use the land in another administrative unit where they were not officially registered as residents.

Nowadays, Bru-Van Kieu households' landholdings are merely remnants of their traditional area. Although there were no statistics on land holdings among the Bru-Van Kieu in Katup Village before 1975, a transnational comparison of current landholdings may suggest that the Bru-Van Kieu in Katup Village suffered a huge loss in access to agricultural land. The Laotian Bru-Van Kieu respondents estimated that each of their households in Katup Noy Village, across the Sepon River, had on average seven to eight hectares of swidden land. Traditionally, indigenous Bru-Van Kieu need a large landholding if they are to sustain their shifting cultivation practice. By dividing the uncharted territory into small administrative units, the official authority confined the production space of the Bru-Van Kieu people. For the first time, traditional, shifting cultivation became unlawful because it would, by its expansive nature, violate the political boundaries drawn by the State. While establishing official boundaries "unintentionally" reduced the land that was accessible to the Bru-Van Kieu and created institutional barriers that reduced traditional production space, the immigration of the Kinh people put further pressure on land. From 1976 to 2011 the population of Lao Bao Town quandrupled as a result of immigration of Kinh people from lowland (Fig. 3). Together, these factors resulted in a sharp decrease in landholding among indigenous households, which was necessary for the viability of their traditional subsistence farming.

Figure 3. Population of Lao Bao Town, 1976-2011 ${ }^{16}$.

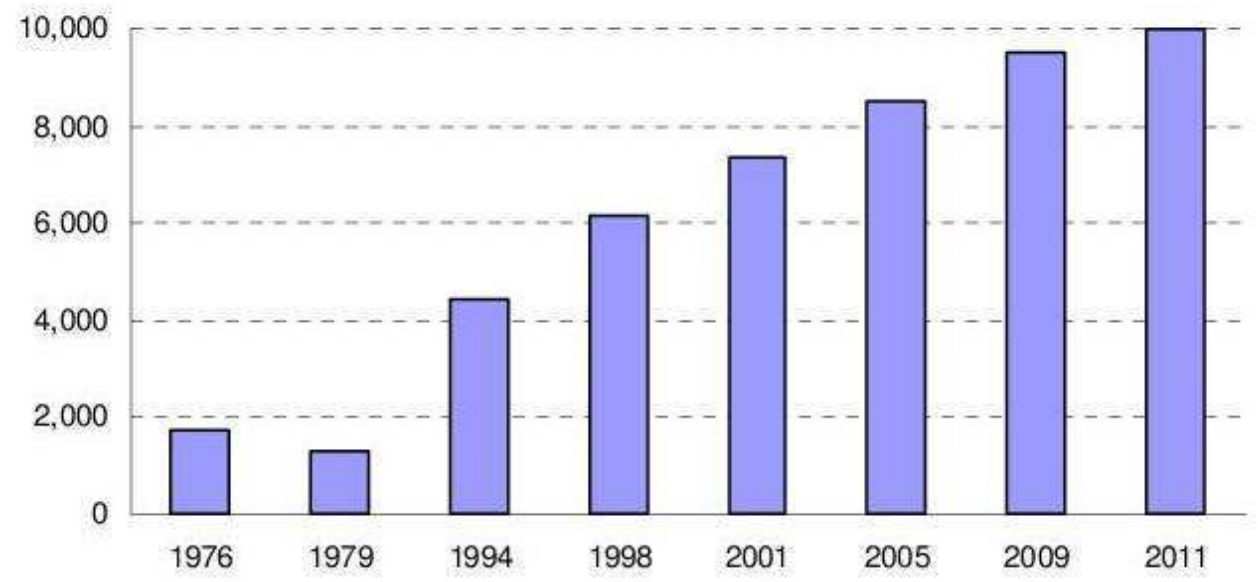




\section{The decreasing role of the traditional governance system}

An important function of the traditional governance system in the Bru-Van Kieu society was the management of land as a common pool resource and the maintenance of fairly equal land allocation among clans and households in the village. In the process of expanding its power to the periphery, the State institutionalised land resources and replaced the traditional governance system for allocating land. As a result, the traditional governance system gradually diminished. Dang Dinh Trung (2003) indicated that in the Central Highland legally protected changes in land relations from communal land to private ownership relegated the influence of the informal decision-making system. $\mathrm{He}$ pointed out that the polan, a traditional decision maker who allocated land and forest resources and sanctioned violations of land-related religious prescriptions became a symbolic figure in charge of celebrating the worship of the land spirit when the land was officially allocated to individual households. Another study among the Katu people, another ethnic minority sharing various cultural and political similarities to the Bru-Van Kieu people in the mountainous area of Central Vietnam, has shown that the indigenous local governance system was fighting a losing battle against the rising and more powerful official ruling system (Nguyen and Kim, 2013).

In Katup Village, official institutions had been heavily challenging the traditional political system since 1975; nonetheless at that time the Bru-Van Kieu still unconditionally respected and observed the decision-making role of the patriarch, the symbol of the traditional governance system. Starting in the mid-1990s, when Lao Bao Town became the focal point in the development plan for Quang Tri Province, the power struggle between the traditional and official systems began to shift further in favour of the latter. At this time, the official institution departed from its early administrative role over land and people at the village level to a more penetrating involvement at the household level, through rural development schemes such as poverty eradication, family planning, mandatory primary education, and healthcare. James Ferguson argued that implementing development projects was the basis for extending the power of the State and a tool for building governmental presence from a distance (Ferguson, 2006). The evidence of increasing State power at the village level can be found in the emergence and rise of the village headman, an officially appointed position. In the late 1990s, an elder ${ }^{17}$ was chosen by Lao Bao Town People's Committee, the main official authority, as the first village headman to watch over official programmes. This marked the start of the official presence of a State representative at the village level, even though subtle influences have been in place since 1975.

In the context of increasing interaction with official institutions, the village headman becomes a stronger figure in village politics while the patriarch becomes weaker. The official system does not deal with Katup Village as a collective entity, but rather as individual households. Each household and member was provided with a set of different official certificates ${ }^{18}$, which is required when that household works with the official authorities. Applying for these certificates is time-consuming and troublesome, even for Vietnamese Kinh. The position of the village headman therefore became important, because he is able to assist his villagers in acquiring these documents by understanding how the procedure works and by translating between his native language and the official Vietnamese language, the former of which is spoken by very few officials. Table 2 
illustrates the power division between the village headman and the patriarch. At first, a village headman may only be a bridge between the official authorities and villagers. Gradually, as the daily activities of each Bru-Van Kieu household became interwoven into official schemes and programmes, the village headman becomes the real leader, replacing the patriarch. All of the Katup villagers agree that, nowadays, the village headman is more important than the patriarch. The significance of the latter is confined to ritual works and to maintaining "hòa thuận" [harmony] between member households in the village. The fact that the patriarch's role is diminishing in the community, where his role represents power, indicates the descent of the traditional governance system, in contrast to the rise of State influence.

Table 2. Current power divisions in Katup Village.

\begin{tabular}{|c|c|c|}
\hline & Headman & Patriarch \\
\hline Status & Official/customary & Customary \\
\hline Assignment & $\begin{array}{l}\text { Nominated by the commune } \\
\text { authority and later agreed upon } \\
\text { by the villagers }\end{array}$ & $\begin{array}{l}\text { Automatically obtained status of } \\
\text { the "già làng" [patriarch] because of } \\
\text { his age }\end{array}$ \\
\hline Tenure & $\begin{array}{l}\text { Five-year term (maximum two } \\
\text { terms) }\end{array}$ & $\begin{array}{l}\text { Begins when the last patriarch } \\
\text { dies, and remains as long as he is } \\
\text { conscious }\end{array}$ \\
\hline Official reward & Monthly allowance & None \\
\hline Criteria & $\begin{array}{l}\text { Acquired a high-school degree, } \\
\text { or at least attended high-school in } \\
\text { the official education system }\end{array}$ & $\begin{array}{l}\text { Deep understanding of ritual } \\
\text { works }\end{array}$ \\
\hline Function & $\begin{array}{l}\text { Frequently reports to the } \\
\text { commune authority about village } \\
\text { business } \\
\text { Facilitates the implementation } \\
\text { of state policies at the village level } \\
\text { A bridge between the official } \\
\text { authority and villagers }\end{array}$ & $\begin{array}{l}\text { Performing ritual works } \\
\text { Peace-keeper among } \\
\text { households }\end{array}$ \\
\hline
\end{tabular}

SOURCE: fIELD SURVEY, JULY 2013

In summary, the Bru-Van Kieu in Katup Village are being denied their full traditional social and economic life. When coercively included into political economy system of the ethnic majority, they are marginalised.

\section{Local responses}

This final section investigates how the Bru-Van Kieu in Katup Village responds to the unfavourable socio-economic and political changes that were brought about by the State development policies. The long-term adaptation of an ethnic minority to a new political reality is dependent on both macro factors, such as the national agenda, and local specifics, such as their location, languages, history, and cultural proximity to lowland majorities (Michaud and Forsyth, 2010). It is, therefore, the authors' intention to determine the local specifics affecting the Bru-Van Kieu people's responses to external normalizing factors. 


\section{Preservation of village culture}

Polygamy was an essential part of traditional Bru-Van Kieu society, since the high demand for males in the extended farming system implies that an additional wife offers additional labour and the possibility of more male offspring. The modern economy of the Bru-Van Kieu has significantly transformed from traditional shifting cultivation. Furthermore, the practice of polygamy is prohibited by official law. Despite all of these modern obstacles, the Bru-Van Kieu males in Katup Village still practice polygamy, although admittedly in smaller numbers ${ }^{19}$. The Bru-Van Kieu have widely accepted polygamy as an unquestionably traditional social norm, despite knowing that the practice is against official rules. Mr. Mung, the headman of Katup Village, is the local representative of the State, as well as a member of the village community. Mr. Mung's daily behavior reflects his dilemma of political dualism. Mr. Mung has not reported polygamy cases in his village to the commune authority, although this task is seemingly his duty as the representative of the official bureaucratic system. On the contrary, he helped to legalise the children of a second spouse ${ }^{20}$. To some extent, we can consider the village headman in Katup Village as the locus at which State power and village tradition merge and clash. His dualism, between the position of a State representative and a BruVan Kieu, between performing his official duty and his obligation to tradition, further solidifies the concept that the border area is the sphere at which official power and local, traditional institutions are merged and contested.

Another aspect of traditional Bru-Van Kieu society, which is still frequently practiced in the present, is labour-exchange. The intensive assignments that a family may engage in such as collecting firewood, preparing land, harvesting crops, and constructing houses often attract voluntarily labour from other villagers. This is a popular village norm that was practiced to different degrees by all of the houses in the village that were interviewed. Traditionally, at the end of dry-rice harvest period, which usually falls at that end of March and consists of activities that attract intensive labour-exchange in a short period of time, the Bru-Van Kieu celebrate a festival called "cúng lúa mới", which loosely translates as "greeting newly harvested rice". The festival,which consists of slaughtering water-buffalo, swine, and chickens, and drinking that lasts for several days,is condemned by official authorities as superstitious, wasteful, and unnecessary, and is therefore prohibited. Nonetheless, the Bru-Van Kieu people in Katup Village continue to celebrate "cúng lúa mới", at the village scale in a more covert form. The villagers no longer slaughter water buffalo for this festival, because they are too expensive for even the village to collectively afford. In addition, they may organise the festival after they have harvested and sold their industrial cassava, which occurs once a year.

\section{Social and livelihood space beyond the reach of the State}

Unconsciously or not, the Bru-Van Kieu have downplayed the importance of the political border as much as they can by maintaining social relations and activities across a geographic area that is unobstructed by political boundaries. The physical gap, in the form of Sepon River, and the political barrier are made insignificant by daily bordercrossings via a boat, operated by a Katup family, which transports people, motorbikes, and goods across the river, without requiring travelers to present their travel document. 
Existing during the reign of the passport, such cross-border movement attract our attention because it challenges the nature of a seemingly established system. also cross the border on daily basis for their livelihood activities, which include collecting forest products and practicing of swidden farming 22 . While collecting NTFPs and extracting timber has traditionally been done by Katup villagers, even on the Laotian side, the Vietnamese Bru-Van Kieu's practice of cultivating land in Laos reminds us of a strategy for negating the adverse impacts that stem from the loss of land used for shifting cultivation and the conversion of land over to commercial crops. Faced with the land deprivation on the Vietnamese side, the Bru-Van Kieu in Katup Village, as well as the Kinh people in Lao Bao Town and its neighbour communes, look for sparsely populated areas in Laos where they might cultivate cash crops, especially bananas, thanks to the better soil fertility found there. Agricultural land in this remote corner of Laos is beyond the strict, official jurisdiction, and practically under customary control of the Laotian Bru-Van Kieu; hence, their Vietnamese co-ethnics could acquire land for production by borrowing it from their Laotian co-ethnics. The borrowers are usually families in Katup Village who have become landless after engaging in the cash-crop economy, or families whose land was unproductive. The right to borrow and the obligation to lend land may sound unfamiliar to outsiders, but for the Bru-Van Kieu people, it is a popular social norm from the past that follows the principle of reciprocity and mutual help. Mr. H, a Bru-Van Kieu household head in Katup Village in Laos said that "... he has no land but a family to feed. I have spare land that I can survive without. Letting him borrow the land to plant crops is the right thing to do" (Field survey, 2013).

border activities exercised by the Bru-Van Kieu. Their tolerance of "illicit" activities may stem from several reasons: first, local law enforcement are short in staff and finance; second, so-called "illicit" activities generate rent-seeking opportunities for the local officials.

\section{"Them" and "us"}

It is true that, even before the demarcation of the international border, the Bru-Van Kieu people had been travelling, unhindered by the river, around the area to collect forest products and practice farming. If cross-border activities among the Bru-Van Kieu who live in Katup Village do not coincide with the unfavourable changes that have occurred in their surroundings over the last 40 years, how can they be considered as reactionary? We argue that, even though the activities were not unprecedented, the Bru-Van Kieu consciously interpreted their actions in a different manner. In other words, their 
reactions were an attempt to bridge the enormous economic and political gap in order to bring themselves some advantage in their unequal struggle against the State and the dominant majority. The following examples, both of which illustrate the preferential treatment of co-ethnics by the Bru-Van Kieu people, will further elaborate on the above argument.

As mentioned above, both the Kinh and Bru-Van Kieu use a boat, operated by a Bru-Van Kieu family living in Katup Village, to cross the Sepon River. The boat's owner- operator gives preferential treatment based on ethnicity. He never asks for a fee when transporting ${ }^{23}$ his Bru-Van Kieu co-ethnics, regardless of whether they are Laotian or Vietnamese. As for Kinh travellers, however, there is always a cost.

In another example, although there are both Kinh and Bru-Van Kieu farmers cultivating land belonging to the Laotian Bru-Van Kieu people, the Laotian landowners' treatment of these two ethnic groups is different. The relationship between Laotian landowners and Kinh farmers is that of an owner-renter, in which the latter have to pay a fair sum of money to the former in order to rent their user rights. At the same time, the relationship between the Laotian Bru-Van Kieu and their Vietnamese co-ethnics is that of an ownerborrower, in which the latter does not make any monetary payments (Table 3). This is because the Bru-Van Kieu developed a perception that, unlike the Katup Bru-Van Kieu who borrowed the land to supplement their household economy, the Kinh farmers were after profit ventures.

Table 3. Laotian Bru-Van Kieu's different treatment of Vietnamese farmers on the basis of ethnicity.

\begin{tabular}{c|c|c}
\hline & Kinh farmers & $\begin{array}{c}\text { Bru-Van Kieu farmers in } \\
\text { Katup }\end{array}$ \\
\hline Land tenure & Lease land & $\begin{array}{c}\text { Borrow land (no payments } \\
\text { the landowner*) }\end{array}$ \\
\hline Land size & Large (three to four hectares) & Small (less than one hectare) \\
\hline Tenure duration & $\begin{array}{c}\text { Tenure expires when banana } \\
\text { trees are no longer productive } \\
\text { (usually after three years) }\end{array}$ & $\begin{array}{c}\text { Tenure lasts as long as } \\
\text { needed by the borrower }\end{array}$ \\
\hline $\begin{array}{c}\text { Laotian Bru-Van Kieu's } \\
\text { view on Vietnamese farmers }\end{array}$ & Agricultural entrepreneurs & Farmers for subsistence \\
\hline
\end{tabular}

*THE ANNUAL LAND TARIFF, PAID VIA THE HEAD OF VILLAgE-gROUP TO THE DISTRICT AUTHORITY, AT 30,000 LAOTIAN KIPS (EQUIVALENT TO USD 4), IS NOT CONSIDERED AS A SUBSTANTIAL AMOUNT BY LOCAL STANDARDS.

SOURCE: fIELD SURVEY, JULY 2013

\section{"Illicit" timber relationship}

As mentioned earlier, there is a small number of Bru-Van Kieu households engaging in the more lucrative timber smuggling from Laos to Vietnam. Although deemed illicit, at village level this activity is made possible by the relationship between these Bru-Van Kieu villagers and members of Border Patrol stationed in the post at the very the entrance to the village. According to one Bru-Van Kieu timber smuggler, they pay bribe directly to these Border Patrol men at about 40 to 50 per cent of market value of timber successfully smuggled from each trip, estimated at around USD 800-1000. These bribes would guarantee them no interference during the transport made by motorbike to Kinh buyers 
outside their village ${ }^{24}$. Apart from "safe passage" of their timber to the buyers, the BruVan Kieu are frequently provided with information from local Border Patrol of specific time window when law enforcement officers from higher chain of command visit local area. During these visits, strict rules are applied to cross-border any illicit activities, disregarding any on-going arrangements between local Border Patrol and villagers. From the local Border Patrol's perspective, the revenue gained from smugglers enable them to carry out what they call as "dân vận" (public relation) operation ${ }^{25}$ at village level. In addition, creating a close relationship with those Bru-Van Kieu having extensive crossborder economic engagement helps Border Patrol gain information about other informal conducts in border area. This information is important in making periodic report to higher command justifying their request for further investment of financial and human resources to strengthening border security.

\section{Discussion}

\section{From moral economy to market economy}

In this article we argue that official interventions and market intrusions in Lao Bao Town have resulted in the social and political marginalisation of the Bru-Van Kieu people in Katup Village. This case study shows that livelihood and culture are highly interwoven in the transformation in Bru-Van Kieu society, first transforming their livelihood, then the loss of their traditional shifting cultivation, and finally expanding to the cultural and political domain, resulting in, for example, the demise of their traditional power structure. Changes in livelihood can lead to serious deterioration in the ethnic minorities' culture and identity, which extend beyond the understanding of planners and practitioners and may prompt resistance from the beneficiaries. This calls for understanding the term "better-off" from the perspective of ethnic minorities rather than from a national majority's definition of development. The theme of this paper is not to suggest that the Bru-Van Kieu people object to change. Like in any other societies, they are interested in improving their standard of living and lessening their daily hardship. They resist because the changes, brought about by State development policy and market liberation, are too drastic to the degree of threatening the existence of the cultural and economic world that the Bru-Van Kieu understand. In this case, the response of the BruVan Kieu can be seen as a classic example of Scott's school of "moral economy" and " everyday resistance". One of the most important assets of the Bru-Van Kieu people in Katup Village is their cultural capital, which they share with their cross-border coethnics. The dense network of kinship, history, and language shared with their co-ethnics creates a social space that enables the Bru-Van Kieu people to escape from the total control of the powerful State. Norms defining resource use in this transnational and traditional community become useful tools for the Katup villagers to use when mitigating the impact of the official institutionalisation of resources and of market penetration. Although cross-border farming and NTFPs collection are purely livelihood activities, maintaining these activities also means conserving their culture and a development agenda that is not in line with the State's definition of national identity. The authors strongly believe that the Bru-Van Kieu villagers in Katup Village do not think that their daily activities are acts of resistance against the State's agenda. However, their form of subtle resistance seriously questions the power of the State at its border, because it 
undermines the very first objective of the State in creating international border, which is to build a homogeneous political space, from the centre toward the edge of the society, within which the State can effectively exercise its power.

This case study, however, also illustrates elements supporting Samuel Popkin's (1979) model of rational self-interest and utility-maximizing peasant behavior. The behavior of small number of Bru-Van Kieu timber smugglers proves that decision to engage in crossborder activities is not only a reaction to loss of subsistence economy, preservation of traditional mobility but also rational economic calculation. The fact that cross-border timber smuggling is made possible transnationally based on both traditional network of kinship and relationship with State actors implies that the Bru-Van Kieu employ both moral economy and market economy principles to sustain their livelihood. While the transaction with co-ethnics on Laos territory is based on traditional sense of mutual help and ethnic cultural capital, the transaction with Border Patrol on Vietnam side is calculated on perception of market risk and shared benefits with State and non-State actors. Different from moral economy in which actors show great effort to minimise risks, the Bru-Van Kieu in Katup Village are well aware of the benefit and also the risk accompanying their smuggling activities when dealing with actors outside of their ethnic moral network. A Bru-Van Kieu engaging in timber smuggling stated that he would not abuse the relationship with their cross-border co-ethnics as he only maintains a certain number of cross-border smuggling trips enough to keep his household economy above average despite constant demand from Kinh intermediate for more supply. His reasoning is to not upset fellow villagers or cross-border co-ethnics by becoming too engaging in becoming rich. The act of smuggling represents the mentality of a rational Bru-Van Kieu peasant who tried to strike a delicate balance between moral and market economy principles.

41 This analysis shows that the Bru-Van Kieu are not passive agents of the development process as they can utilise both traditional and official resources to support their livelihood. The study resonates with Forsyth (2009, p. 271) in reminding us to be careful not to fall into the pitfall of "resistance mentality" which "assuming State-society relations are always about resistance, or that certain groups are unwilling to accept changes, or that change must necessarily instill resistance".

\section{State-making by accommodating informal activities}

Before the intensification of cross-border official trading, the State exercises a relaxed degree of border control. To the locals the border was an abstract concept at the time because they were free to roam the area and there was not significant presence of State representatives at local levels to remind them that they are in fact crossing from one State to another. Since the increase of cross-border trade, the State has emphasised on controlling the flowing of material and people for taxation, as well as preventing smuggling. The increased presence of law enforcement, along with popular education on the topic of border and sovereignty change the perception of local people of border realities. Despite official education efforts, local peoples interpretation of the State's concept of territory is influenced mainly by economic and social interest. The difference in level of official investment in infrastructure development projects providing electricity, clean water, housing, education and health care creates a sharp contrast in socio-economic settings on the two sides of the border and provide locals people with a 
hardened line of separation. Local people may accommodate the State's concepts of territory without necessarily abandoning indigenous concept. Cross-border farming and ethnic/cultural interactions point to the prevalence of traditional space which is barely affected by official territorial boundaries. The Bru-Van Kieu make use of official definition of territory to their advantage to exploit other ethnic groups economically (e.g making money from Kinh people passing the border on boat) or newly created economic opportunities (e.g the smuggling of timber, collection of forest products across border to supply domestic demand brought about by the exclusion from resources access). At the same time, they challenge this very concept through activities deemed illegal and subversive from the official perspective. The State does not have enough financial and human resources to exercise maximum enforcement of political borders. As a result, it cannot create an absolute authority on border people. Within its limited resources, the State places its priority on controlling territory and natural resources more than on controlling local population and their cultural geography.

With increasing transnational trade, the need to control local populations becomes more urgent, thus the State increases its presence in the border area. However, de jure territorial control does not automatically translate into de facto power over the population on this territory because before the imposition of official rules, human space/ geography in this area was governed by traditional and indigenous laws. What is, then, the actual process of official enforcement and regulation in the border area? In order to set control on local border population, the State relies on practical rules resulting from negotiation and compromises with local activities. These rules, established via negotiation with local actors grant the State space to exercise its authority, admittedly partial, regarding the cross-border flow of people and material. The fact that States come to being through the practical exercise of these rules supports the argument that the State is not a monolithic entity. In fact it is an effect of the practices and interactions between different State and non-State actors.

Border making is not a passive notion or simple line drawn on the map but an active process involving different State and non-State actors that may provide a closer look into State-society relations. The authors argue that it is State-territorialisation, by creating a zone of exclusion or inclusion that has created a constructed space where State and nonState actors constantly contest. Although the practices of State representatives at local level conflict with what they are mandated to, they are in fact part of State-making. Through negotiations between local officials and ethnic minority people which results in compromises and tolerance of illicit activities, the State starts to set practical rules and gradually gain a foothold in an area which until recently was still out of reach from the State authority. This analysis implies that the process of State-making is based on local specifics. That is to say the State might have to compromise their indivisible and monolithic nature to accommodate "illicit" activities and informal rules to be able to gain the first stepping stones to gain authority. From the local people's perspective, accepting State authority at village level can be seen as a gain because the relationship forged with local State actors enable the Bru-Van Kieu to operate in a quasi-official mode with people of different ethnicity beyond their social familiarity for economic gain. 


\section{Conclusion}

This paper describes the dynamics between State-territorialisation in the border area, understood as a strategy of State-making and enhancing the State's authority, and responses of local people. Exercising internal territorialisation by establishing administration over people and resources, the State has marginalised local ethnic minority group leading the latter to seek intensification of cross-border use of natural and cultural resources. This, in turn, compromises the sovereign aspect of Stateterritorialisation. Sovereign-territorialisation, aiming at creating a State boundary within which a universal set of official rules can be applied, is threatened by the re-invention of traditional ethnic institution. Not abandoning its objective of establishing rules for all subjects within its sovereign, the State gives concession to border citizens for the use of informal rules regarding cross-border flow of human and resources. It should, however, be reminded that this relationship between State rules and informal rules is under constant re-negotiation. The analysis that while the State can be accommodating, local ethnic minority people are also not passive but are able to use their tradition agencies to negotiate with more powerful actor helps dismantle not only the image of a rigid, uncompromising and monolithic State but also the view that ethnic minority people are passive beneficiaries of macro State and economic processes. While the political behavior of Bru-Van Kieu people is in resonance with Scott's school of moral economy and everyday resistance, it would be for the benefit of ethnic groups in general if researchers and development planners are careful not to portray them in overly romanticised or " traditional" settings that deny their ability to take advantages of new official and market opportunities.

\section{BIBLIOGRAPHY}

CLARKE G., WILLIAM J. (2007), Expendable warriors the Battle of Khe Sanh and the Vietnam War, Westport, Conn., Praeger Security International.

DANG T. (2003), “Coffee Production, social stratification and poverty in a Vietnamese Central Highland community”, in DE-KONINCK R., GENDRON B. \& LAMARRE J., Understanding poverty in Vietnam and the Philippines: concepts and context, Montreal, University of Montreal and University Laval.

DFID (2009), Building the State and Securing the Peace, London, UK Department for International Development.

FERGUSON J. (2006), “The anti-politics machine”, in SHARMA A., The anthropology of the State: a reader, Oxford, Blackwell Publication.

FORSYTH T. (2009), “The persistence of resistance: analyzing responses to agrarian change in Southeast Asia", in CAOUETTE D., TURNER S., Agrarian Angst and Rural Resistance in Contemporary Southeast Asia, London, Routledge. 
HICKEY C. (2002), Window on a war an anthropologist in the Vietnam conflict, Lubbock, Texas Tech University Press.

KERKVLIET B. (2005), The Power of Everyday Politics: How Vietnamese Peasants Transformed National Policy, Ithaca, Cornell University Press.

LE D. (1776), Phủ Biên Tạp Luc [A compilation of the miscellaneous records when the southern border was pacified] (Dao A., Trans), Hanoi, Vietnam Culture and Information Publishing House.

LE O., PHAN T. \& DUONG H. (1993), History of Communist Party Cell in Huong Hoa District 1930-1975, Quang Tri, Quang Tri Printing.

LI T. (1998), Nguyen Cochinchina: southern Vietnam in the seventeenth and eighteenth centuries, New York, Southeast Asia Program Publications.

MCELWEE P. (2008), “'Blood relatives' or uneasy neighbors? Kinh migrant and ethnic minority interactions in the Trường Sơn Mountains “, Journal of Vietnamese Studies, 3, 3, pp. 81-116.

MICHAUD J., FORSYTH T. (2010), "Rethinking the Relationships between Livelihoods and Ethnicity in Highland China, Vietnam, and Laos", in MICHAUD J., FORSYTH T., Moving mountains: ethnicity and livelihoods in highland China, Vietnam, and Laos, Vancouver, University of British Columbia Press.

NGUYEN A., KIM DC. (2013), "Inter-ethnic assimilation and differentiation in rural development: Local response to forestry land allocation in Vietnam", in CAWLEY M., BICALHO A. \& LAURENS L., The sustainability of rural systems: Local and global challenges and opportunities, Galway, Whitaker Institute, NUI Galway and CSRS of the International Geographical Union.

NGUYEN H. (1984), “Van Kieu peoples”, in NGUYEN L., Ethnic minority peoples in Binh Tri Thien Province, Hue, Thuan Hoa Publisher.

NGUYEN M. (2001), Customary laws of the Taoih, Katu and Bru-Van Kieu in Quang Tri and Thua Thien Hue Province, Hue, Thuan Hoa Publisher.

NGUYEN N.G. (2009), Early Storms [Cơn lốc đầu mùa], Hanoi, The Publisher of the People's Army. NGUYEN S., NGUYEN H. (2010), History of Communist Party in Lao Bao Town 1975-2005, Lao Bao, Communist Party Cell of Lao Bao Town.

OECD (2008), State Building in Situations of Fragility - Initial Findings, Paris, OECD.

PINGALI P., VO X. (1992), “Vietnam: Decollectivisation and rice productivity growth”, Economic Development and Cultural Change, 40, 4, pp. 697-718.

POPKIN S. (1979), The rational peasant: the political economy of rural society in Vietnam, Berkeley, University of California Press.

PHOLSENA V. (2008), "Highlanders on the Ho Chi Minh Trail”, Critical Asian Studies, 40, 3, pp. 445-474.

SCOTT J. (1976), The moral economy of the peasant: rebellion and subsistence in Southeast Asia, New Haven, Yale University Press.

SCOTT J. (1985), Weapons of the weak: everyday forms of peasant resistance, New Haven, Yale University Press.

SCHROCK J., STOCKTON W., MURPHY E. \& FROMME M. (1966), Minority Groups in the Republic of Vietnam, Washington D.C., Department of the Army.

STUART-FOX M. (1995), “The French in Laos, 1887-1945”, Modern Asian Studies, 29, 1, pp. 111-139. 
VANDERGEEST P., PELUSO N. (1995), “Territorialisation and State power in Thailand”, Theory and Society, 24, 3, pp. 385-426.

\section{NOTES}

1. Phủ biên tạp luc is compilation of miscellaneous records when the southern borderland was conquered. The record included noted various governing activities of Nguyen lords in frontier area. It was originally written in a traditional script based on Chinese style by Lê Quý Đôn in 1776 and translated into modern Vietnamese alphabet by various authors. In this paper, the version translated by Đào Duy Anh in 2007 was used.

2. The Nguyen includes nine lords who governed Cochinchina from 1558 to 1776 and 13 kings who were directly descendants of these Lords officially rule the country from 1802 to 1945.

3. Thuan Hoa is a historical term indicating a geographic area including modern Quang Tri Province and Thua Thien Hue Province

4. Precursor of modern Socialist Republic of Vietnam

5. Annamite Cordillera or "Trường Sơn" in Vietnamese is the mountainous range separating Laos and Vietnam extending to nearly $1,100 \mathrm{~km}$.

6. Meaning "Small Katup".

7. The Katup-Ma Hat Village Group, consisting of four villages stretching nearly seven km along the Sepon River, has its administrative centre in Katup Noy Village, on the Laos side of the Sepon River, just opposite Katup Village. Unlike Vietnam where administrative system is wellstructured in a hierarchy from central level to provincial level, then to district level and lastly, to commune level, the same system in Laos is designed only to district level. In the absence of government system at local level, Katup-Ma Hat Village Group is governed by customary rules. There is a presence of Laotian Border Patrol in the area, however, their task is not to administer local population but mainly to protect territorial integrity. For the remainder of this article, the term Katup Village only refers to the Bru-Van Kieu village on Vietnam side of the border, unless otherwise stated.

8. Bollywood is common name of Litsea glutinosa, a rainforest tree species.

9. Popular name for Land Use Right Certificate. This official certificate, awarded to household, does not recognise a well-demarcated land plot as household's property but only the right to use the land for certain duration.

10. Delay in official issuance of Red Book for Katup villagers is only a matter of technical issue.

11. Industrial cassava local-type KM49 is suitable for nutrient-poor soil.

12. Wild bananas are a popular product among Kinh buyers. A bitter banana, full of hard seeds, is submerged in rice-wine to enhance its flavour for domestic use. Banana flowers appeal to Kinh housewives, because they can be used in making a variety of dishes.

13. Girls as young as 12 to 13 years old also engage in collecting NTFPs. However, the gender dimensions and child labour involved in these tasks are not discussed in this paper.

14. A group of three to four male kinsmen venture into Bru-Van Kieu territory, and even BruMakong territory in Laos, to purchase processed timber. The timber is already harvested, dried, and sawn to fit the capacity of a normal motorbike. While the job of collecting timber among the Laotian Bru is less risky because the sparse Laotian law enforcement cannot control daily activities in the forest, the occasional transport of timber into Vietnam is more risky because of the presence of forest rangers and police at multiple checkpoints along the road. Therefore, the men usually use a cheap and expendable motorbike for the task. If they encounter Laotian law enforcement, they would abandon both their motorbike and timber and run away. Although the job is high-risk and becoming more difficult, it brings more profit than other livelihood activities. After transporting timber from Laos, they sell it to intermediaries in Lao Bao Town, 
who in turn will transport it to lowland urban markets. If successful, each member of the group may see a profit of two-to-three million VND (USD 100-150) from each timber-smuggling trip to Laos.

15. Tan Kim 2 was one of seven newly established village-based production units in Lao Bao in 1975including Duy Tan, Cao Viet, An Ha, Tan Kim 1, Tan Kim 2, Xuan Phuoc, and Vinh Hoa.

16. The population decreased in 1979 when a group of Kinh households could not adapt to the natural and social conditions of Lao Bao Town and returned to their original commune. The date is collected from several Huong Hoa District Statistical Year-books for 1991-1995, 1995-1998, 1997-2001, 2005, and 2011.

17. This male elder fought in a local guerrilla-army that was heavily connected to the prosocialist provisional district government during the war; hence, he had vast experience with official business. Lao Bao Town People's Committee must have seen this elder as an ideal messenger between the State authority and the villagers.

18. The household registration book, personal identity card (for individuals 16 years and older), health insurance card, land-use-rights certificate, birth certificate, and the marriage certificate.

19. There are four polygamous households in Katup Village.

20. Because the system does not recognise the second wife, all newborns of the second spouse are officially registered as children of the first wife.

21. There are five housewives who initially were of Laotian having converted to Vietnamese citizenship by marriage in Katup Village.

22. Among 72 households in Katup Village, 69 engaged in daily collection of non-timber forest product such as bamboo sprout, fuel wood, bird, bee honey and porcupine's stomach, 25 in swidden farming; and 38 in timber extraction such as teak in Laos territory

23. The fee was about VND 10,000 (equivalent to USD 0.5) as of mid-2013

24. Official barriers from their village where they usually store their smuggled timber before dispatching to their next destination of Kinh intermediate living along the main National Highway or Kinh carpenters in Lao Bao Town includes not only Border Patrol but also Public Security, Market Control, Tax and Traffic Control. Nonetheless, the bribe to Border Patrol is oneoff as they do not have to trickle their profit to other law enforcements. Without further detail, the Bru-Van Kieu suspect that their bribe would be divided among these forces.

25. Includes but not limit to dissemination of different national policies, organizing of soldiervillagers meetings in national celebration days to instill a sense of national identity.

\section{ABSTRACTS}

The human geography of Vietnam's upland area has been transformed significantly during the last 40 years due to the increasing control from the central government. We argue that State territorialisation, understood as a strategy of State-making and assertion of the State's authority, has the tendency to marginalise, socially and politically, local ethnic minority peoples by excluding them from indigenous social and economic geography and the use of natural resources. At the receiving end of these official policies, the local ethnic minority people do not passively accept their marginalisation but are able to initiate the use of traditional cross-border cultural resources to improve their condition. By analysing the tolerance from local official towards illicit cross-border activities daily carried out by local people, the case study provides 
some insights on the dynamics of power struggle between the State and local people. We concluded that local ethnic minority peoples actively re-negotiate with more powerful State and economic actors and re-shape local border politics while the State is not always uncompromising and monolithic as it is usually portrayed.

La géographie humaine de la zone montagneuse du Vietnam s'est considérablement modifiée au cours des 40 dernières années en raison du renforcement du contrôle exercé par le pouvoir central. Nous argumentons que la territorialisation en tant que stratégie de formation et d'affirmation de l'autorité de l'État tend à marginaliser les minorités ethniques locales en les excluant de la géographie socio-politique indigène et de l'utilisation des ressources naturelles. Ces minorités n'acceptent pas passivement cette marginalisation et ont recours à l'utilisation des ressources culturelles traditionnelles transfrontalières pour améliorer leur condition. Analysant la tolérance des autorités locales envers les activités transfrontalières illicites menées quotidiennement par les populations locales, notre étude de cas apporte quelques éclairages sur les dynamiques de la lutte de pouvoir qui les oppose à l'État. Nous en concluons que ces minorités ethniques renégocient activement avec des acteurs étatiques et économiques plus puissants et recomposent les politiques frontalières locales tandis que l'État ne se montre pas toujours aussi intransigeant et monolithique qu'on le dépeint généralement.

INDEX

Mots-clés: Vietnam, territorialisation, minorité ethniques, ressources culturelles transfrontalières

Keywords: Vietnam, State-territorialisation, ethnic minority, cross-border cultural resources

\section{AUTHORS}

\section{TRINH NGUYEN MINH ANH}

Nong Lam University, Vietnam, ntminhanh@gmail.com

DOO-CHUL KIM

Okayama University, Japan (corresponding author), kim@okayama-u.ac.jp

\section{FUMIKAZU UBUKATA}

Okayama University, Japan, ubukat-f@okayama-u.ac.jp 